\title{
HIST1H4I/BCL6 Fusion Gene
}

National Cancer Institute

\section{Source}

National Cancer Institute. HIST1H4I/BCL6 Fusion Gene. NCI Thesaurus. Code C99575.

A fusion gene that results from a chromosomal translocation $t(3 ; 6)(q 27 ; p 22)$ which fuses the HIST $1 \mathrm{H} 4$ I gene near the 5 ' end of the BCL6 gene. This rearrangement is associated with aberrant expression of the BCL6 gene product and B-cell non-Hodgkin lymphoma. 